\title{
Biochemical aspects of a whey fraction capable of promoting hybridoma proliferation. Comparison with fetal calf serum
}

\author{
AF Derouiche 1, C Legrand 1, JM Bour 1, J Capiaumont 1, \\ MA Gelot 1, B Dousset 1, F Belleville 1*, P Nabet 1, G Linden 2 \\ 1 Nancy University I, School of Medicine, Biochemistry Laboratory, \\ BP 184, 54500 Vandœuvre Cedex; \\ 2 Nancy University, Faculty of Sciences, Applied Biochemistry, associated with INRA, \\ BP 239, 54506 Vandceuvre Cedex, France
}

(Received 26 February 1990; accepted 8 June 1990)

\begin{abstract}
Summary - Human and bovine milks were used as serum substitute for cell cultures. Two whey fractions termed LBS65 and LELm prepared by different steps were routinely used for culturing hybridomas in our laboratory. They stimulated ${ }^{3} \mathrm{H}$-thymidine incorporation into hybridoma, but a minimum of $1 \%$ of fetal calf serum ( $F C S$ ) was required when the cells were propagated in the long-term. In this investigation, the chemical composition of LBS65 and LELm was studied in parallel to FCS composition. LBS65 and FCS had a total protein level of about $40 \mathrm{~g} / \mathrm{l}$, while LELm contained them at a concentration of $11 \mathrm{~g} /$. The amino acid content of FCS and LBS65 was very similar (about 4000 $\mu \mathrm{mol} / /$ ), whereas it was lower in LELm (about $300 \mu \mathrm{mol} / /$ ). Although the values of nitrogen compounds were different in LBS65 and LELm, these 2 whey fractions behaved similarly to a substitute of FCS. Whey fractions were low in sodium, and high in calcium compared to FCS. The cholesterol level was lower and triglycerides were higher in whey than in FCS. The ratio of unsaturated/ saturated fatty acids varied from 1 whey fraction to another. It differed from the FCS ratio. FCS and whey fractions contained small amounts of steroid or peptide hormones. However, progesterone, 17-OH-progesterone, ACTH and cAMP concentrations were higher in the whey fraction than in FCS. Whey fractions are a complex medium containing various compounds able to promote cell growth. However, some unknown compounds present in FCS and absent in milk fractions are required in long-term cell culturing.
\end{abstract}

bovine milk / whey / whey hormone / whey amino acid

Résumé - Composants biochimiques du lactosérum pouvant induire la prolifération cellulaire d'hybridomes. Comparaison avec le sérum de veau foetal. Les laits humains ou bovins ont été utilisés comme substitut du sérum dans les cultures cellulaires. Deux fractions de lactosérum, appelées LBS65 et LELm, préparées de façon différente, sont couramment utilisées au Laboratoire pour la culture d'hybridomes. Ils stimulent l'incorporation de ${ }^{3} \mathrm{H}$-thymidine dans des hybridomes, mais si les cultures doivent être faites à long terme, 0,5 ou $1 \%$ de sérum de veau fotal (FCS) reste indispensable. Dans ce travail, est étudiée la composition chimique de LBS65 et LELm parallèlement à celle du sérum de veau fœetal. LBS65 et FCS ont une concentration en protéines totales voisine (environ $40 \mathrm{~g} /$ )), alors que LELm n'en contient que $11 \mathrm{~g} / \mathrm{l}$. De même, les acides aminés sont au même taux (environ $4000 \mu \mathrm{mol} / \mathrm{I}$ ) dans FCS et LBS65 et à des taux faibles dans le LELm (environ

\footnotetext{
${ }^{*}$ Correspondence and reprints
} 
$300 \mu \mathrm{mol} / \mathrm{l})$. Bien que très différentes par leur contenu azoté, LBS65 et LELm se comportent sensiblement de la même façon comme substitut de FCS. Les lactosérums ont, par rapport au FCS, une teneur faible en sodium et élevée en calcium. Le taux de cholestérol est plus bas dans les lactosérums et les triglycérides sont plus élevés. Le rapport (acides gras (AG) insaturés/AG saturés) est très variable d'un lactosérum à l'autre et différent de celui du FCS. FCS et lactosérums contiennent des quantités faibles d'hormones stéroïdes ou peptidiques. II faut cependant noter que les taux de progestérone, 17-OH-progestérone, ACTH et surtout AMPc sont supérieurs dans les lactosérums. Le lactosérum est donc un milieu complexe contenant de nombreux composés dont chacun peut avoir une activité de croissance. Cependant, certains facteurs encore inconnus, présents dans le FCS, qui sont nécessaires à la croissance à long terme des hybridomes, manquent dans les lactosérums.

\section{lait bovin / lactosérum / hormone du lactosérum / acide aminé du lactosérum}

\section{INTRODUCTION}

Human or bovine milk has been used as a serum substitute for promoting cell growth (Serini and Baserga, 1981; Nano et al, 1982). We have shown that bovine whey fractions, a dairy by-product, can also replace fetal calf serum (FCS) in eucaryote cell lines cultured in the short or long-term (Damerdji et al, 1988). However, in the latter case 0.5 or $1 \%$ of FCS must be added to promote long-term proliferation. Furthermore, hybridoma can be stored at $-80^{\circ} \mathrm{C}$ for 2 years in the same milk fractions (Derouiche et al, 1989).

Whole bovine milk contains various compounds able to stimulate cell growth: growth factors (Shing and Klagsbrun, 1984; Campbell and Baumrucker, 1989), vitamins and trace elements (Blanc, 1981; Alais, 1984), hormones (Koldovsky and Thornburg, 1987), peptides with various activities (Maubois and Léonil, 1989). This paper reports the cell growth promoting activity and composition of 2 whey fractions prepared differently, attempts to correlate the composition with their activity and compare them with the composition of FCS generally employed to supplement culture media.

\section{MATERIALS AND METHODS}

\section{Preparation of whey fractions}

The first fraction (termed LBS65) was prepared by Bel (Vendome, France) according to an industrial process. The fats and cell debris were removed by centrifugation $(4500 \mathrm{~g})$ at $5^{\circ} \mathrm{C}$ for $20 \mathrm{~min}$. The skim milk was heated at $67^{\circ} \mathrm{C}$ for 15-20 s and the proteins (mostly casein) were precipitated at $34{ }^{\circ} \mathrm{C}$ with $40 \mathrm{ml}$ of diluted $1 / 1000$ enzyme mixture (chymosin $80 \%$ and pepsin $20 \%$ ) for $100 \mathrm{I}$ of skim milk. The supernatant was heated at $65^{\circ} \mathrm{C}$ for $30 \mathrm{~min}$ and concentrated 18 times by ultrafiltration (mineral membrane cut-off 10000 ). The remaining substance was washed with distilled water and again concentrated 18 times by ultrafiltration at $55^{\circ} \mathrm{C}$. It was then centrifuged twice at $30100 \mathrm{~g}$ for $1 \mathrm{~h}$, then $30 \mathrm{~min}$ after removal of the pellet the supernatant was heated at $50^{\circ} \mathrm{C}$, and sterilized by filtration through a $0.22 \mu \mathrm{m}$ membrane. The fraction LBS65 was stored at $-20^{\circ} \mathrm{C}$.

The second fraction (termed LELm) was recovered during cheese-making (Sodial, Metz, France). The milk was heated at $65^{\circ} \mathrm{C}$ for $30 \mathrm{~s}$, and ultrafiltered through mineral membrane (cutoff 10000 ). The fat content of the remaining substance was adjusted and biological fermentation was carried out for $18 \mathrm{~h}$ and the substance was then pasteurized at $72{ }^{\circ} \mathrm{C}$ for $30 \mathrm{~s}$. Penicillium and $\mathrm{Cl}_{2} \mathrm{Ca}$ were added and biological maturation pursued for $1 \mathrm{~h} 35$. The exudate 
was recovered and concentrated 2.5 times by ultrafiltration at $40^{\circ} \mathrm{C}$ (mineral membrane cut-off 10 000). The substance was centrifuged twice for $1 \mathrm{~h}$, then $30 \mathrm{~min}$, sterilized by filtration at $50^{\circ} \mathrm{C}$ through a $0.22 \mu \mathrm{m}$ membrane. The LELm fraction was stored at $-20^{\circ} \mathrm{C}$ in aliquots.

\section{Cell culture}

The hybridom as used in this study were hybridoma $F_{34}$ secreting an $\operatorname{lgG}_{1}$ monoclonal antibody against gonadotropin (gift from Sanofi, Montpellier, France) and hybridoma $\mathrm{A}_{49}$ secreting an IgM monoclonal antibody against blood group A (gift from INSERM, Unité 284, Nancy, France). The cells were routinely cultured in RPMI 1640 medium (Boehringer Mannheim, FRG) supplemented with $10 \%$ FCS (Flow Laboratories, Puteaux, France) heated at $56^{\circ} \mathrm{C}$ for 30 min and $4 \mathrm{mmol} / \mathrm{l}$ of glutamine.

\section{Short-term cell culture and measurement of DNA synthesis}

Hybridoma cell suspension $(100 \mu l)$ were seeded at the concentration of $7 \times 10^{4}$ cells $/ \mathrm{ml}$ in 96 well microtiter plates (Falcon, Grenoble, France). $5,10 \%$ and $20 \%$ of LBS65 or LELm or FCS were added in $100 \mu \mathrm{l}$ of RPMI 1640 and the cells were incubated for $24 \mathrm{~h}$. ${ }^{3} \mathrm{H}$-thymidine $(50 \mu \mathrm{l}, 1 \mu \mathrm{Ci} / \mathrm{ml}$ specific activity $4.5 \mathrm{Ci} / \mathrm{mmol})$ were added for the last $18 \mathrm{~h}$. The cells were collected with Harvester titertek skarton, washed and the radioactivity was counted.

\section{Long-term cell proliferation}

Hybridomas were subcultured in $25 \mathrm{~cm}^{2}$ Falcon flasks every $3 \mathrm{~d}\left(\mathrm{~F}_{34}\right)$ or every $2 \mathrm{~d}\left(\mathrm{~A}_{49}\right)$ in medium containing $1 \%$ FCS and $9 \%$ whey fractions (LBS65 or LELm). For each passage, viable cells were counted using a hemocytometer after the cells were stained with $0.5 \%$ trypan blue and the cell suspension was then brought to $2 \times 10^{5}$ cells/ml and seeded again in a new flask in fresh medium containing the same whey fractions and $1 \%$ FCS. This experiment was stopped at 7 or 90 since our experience has shown that this amount of time is enough to evaluate the ability of the medium to maintain a long-term prolifera- tion. However, we also used the same medium in perfused bioreactors for 3 months (data not shown).

\section{Analysis of whey fractions}

\section{Protein and non-protein nitrogen compounds}

The total proteins were determined by the Gornall's method adapted to SMA II X8 (Technicon, France). Proteins were separated by FPLC according to Andrew's method (Andrews et al, 1985). Amino acids were assayed with a Beckman apparatus (Beckman 7 300) equipped with ion-exchange column (Gelot et al, 1990).

Creatinine was measured with Jaffe's method, uric acid with the uricase method (Boehringer, ref: 242616). These tests were automatically performed on a Prisma apparatus (Analysinstrument Stockholm).

Carnitine was tested according to the radioenzymoassay described by Cederblard and Lindstedts (1972). Histamine was determined by RIA with Immunotech kit (ref: 1 302). $\mathrm{NH}_{3}$ was tested with Berthelot's method (Biolyon-Wako, ref: 31 291).

\section{Minerals}

$\mathrm{Na}^{+}, \mathrm{K}^{+}$were determined by flame photometry (SMA II X8 Technicon), $\mathrm{Ca}^{2+}$ by an automatic (Prisma) colorimetric method using the ocresolphthalein complexon (Sarkar and Chauhan, 1967), iron by the automatic (Prisma) colorimetric method using the ferrozine (Ichida, 1968 ), $\mathrm{Cu}$ and $\mathrm{Zn}$, by flame atomic absorption spectrometry with Pye Unicam 1900 , Philips as apparatus (Arnaud et al, 1984) and Se by flameless atomic absorption spectrometry (PerkinElmer, 2 390) (Dubois et al, 1990). Osmolarity was assayed with an osmometer (Osmaomat 030, Genotec).

\section{Energetic compounds}

Lactose was determined by gas chromatography, using a capillary column $\mathrm{OV}_{1}(250 \times 0.3$ 
$\mathrm{cm}$ ) and silylated derivatives. Other compounds were assayed by enzymatic methods with kits for which the references will be given in the table of results.

\section{Lipids}

Cholesterol and triglycerides were measured with enzymatic methods (cholesterol enzymatic endpoint Randox Laboratories. Triglycerides $800 / 9$, Biolabo) with automatic apparatus (Pris$\mathrm{ma)}$.

Fatty acids (FA) were extracted by Folch's method (Folch et al, 1957). Free fatty acids (FFA) were chromatographed (gas chromatograph, Packard 427) on a carbowax column $(200 \times 0.3 \mathrm{~cm})$ after methylation with methyl 8 (Interchim, Montluçon, France). Total fatty acids (TFA) were measured under the same conditions after alkaline hydrolysis ( $\mathrm{KOH}$-ethanol) and methylation with methanol- $\mathrm{HCl}$ (Garcia et al, 1986).

Vitamins $A$ and $E$ were evaluated by fluorimetric methods (Hansen and Warnick, 1968, 1969 ) and vitamin $D$ by radioimmunoassay (RIA) (Amersham TKR 558).

Peptide hormones and cAMP were assayed by RIA with polyclonal or monoclonal antibodies prepared against human hormones. The references of kits are given with the results.

\section{RESULTS}

Figures 1 and 2 illustrate the hybridoma $F_{34}$ and $A_{49}$ growth at short and long-term in medium containing whey fractions or FCS. Without addition of FCS, whey fractions were able to promote ${ }^{3} \mathrm{H}$-thymidine incorporation into DNA. However, they were less efficient than FCS. When the media were supplemented with $1 \%$ FCS and $9 \%$ whey fractions, the cell proliferation in the long-term was possible. It was as effective as with $10 \%$ FCS. The antibodies secretion was measured on the 7 th $d\left(A_{49}\right)$ or on the 9 th $d\left(F_{34}\right)$. Table I presents the results. Antibodies concentra-



Fig 1. Cell growth measured as ${ }^{3} \mathrm{H}$-thymidine incorporation into DNA. Cell concentration: $7 \mathrm{x}$ $10^{4} \mathrm{cells} / \mathrm{ml}$ in microplate of 96 wells. Each point represents mean and standard deviation of 4 replicates. A: hybridoma $\mathrm{F}_{34}$; $\mathrm{B}$ : hybridoma $\mathrm{A}_{49}$; $\longrightarrow$ fetal calf serum (FCS), $\mathbf{\Delta}-\mathbf{\Delta}$ LBS65, - - LELm.

Mesure de la croissance cellulaire par l'incorporation de ${ }^{3} \mathrm{H}$-thymidine dans I'ADN. Concentration cellulaire de départ: $7 \times 10^{4}$ cellules $/ \mathrm{ml}$ dans des microplaques de 96 puits. Chaque point représente la moyenne et l'écart type de 4 essais. $A$ : hybridomes $F_{34} ; B$ : hybridome $A_{49}$. sérum de veau fotal, $\mathbf{A}-\mathbf{\Delta} L B S 65$, LELm.

tion is as important in medium with whey fraction as in medium supplemented with FCS.

Table II gives the composition in proteins and non-protein nitrogen compounds of whey fractions and FCS. The levels of various compounds were lower in LELm, which has been less concentrated. However, LBS65 and LELm were as effective in promoting growth. 


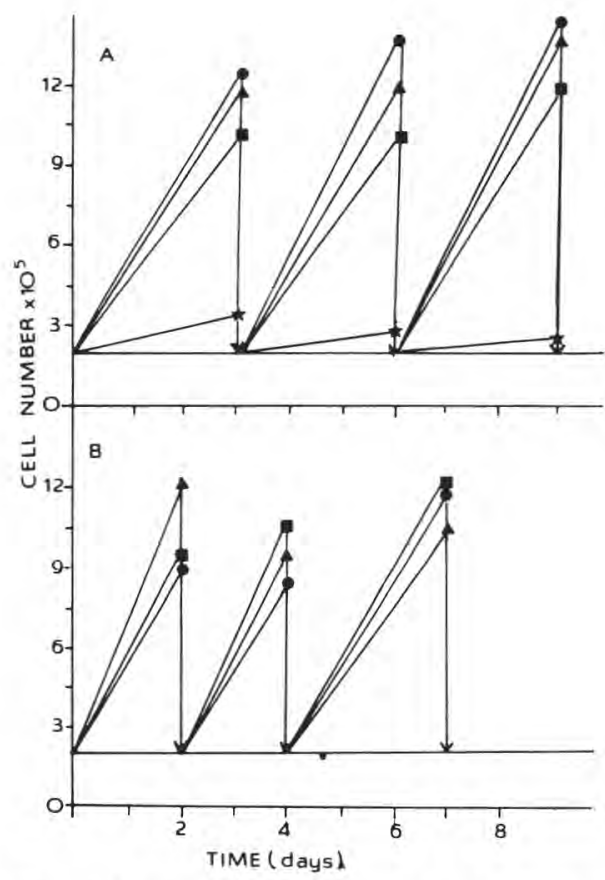

Fig 2. Cell proliferation in the long term. For each passage cell suspension was brought to 2 $\times 10^{5}$ cells $/ \mathrm{ml}$ and seeded in $25 \mathrm{~cm}^{2}$ Falcon flasks. Each point is the mean of 3 counts. A: hybridoma $\mathrm{F}_{34}$; $\mathrm{B}$ : hybridoma $\mathrm{A}_{49}$; $\longrightarrow \mathrm{FCS}$


Mesure de la prolifération cellulaire à long terme. La concentration cellulaire de départ est de $2 \times 10^{5}$ cellules $/ \mathrm{ml}$, elle est ramenée à cette valeur à chaque passage. Culture en flacons de $25 \mathrm{~cm}^{2}$. Chaque point est la moyenne de 3 comptages. A: hybridomes $F_{34}, B$ : hybridome $A_{49}$ - sérum de veau fotal $10 \%$; ** sérum de veau foetal 1\%; $\mathbf{A}-\mathbf{\Delta}$ LBS65, LELm.

Amino-acids and nitrogen metabolites such as creatinine, uric acid and $\mathrm{NH}_{3}$, were still present in LBS65 and LELm although whey fractions were ultrafiltered (cut-off 10 000) and washed.

FPLC analysis of proteins (fig 3 ) showed that $\alpha$ lactalbumin, and $\beta$ lactoglobulin variants $A$ and $B$ were the princi- pal proteins of whey fractions. $\alpha$ lactalbumin represents $23.75 \%$ (LBS65) or $32 \%$ (LELm) of total protein, $\beta$ lactoglobulin variant A $28 \%$ (LBS65) or $10 \%$ (LELm) variant B $39 \%$ or $21 \%$ respectively. Serum albumin and immunoglobulin were found in small amounts. LELm was found to be rich

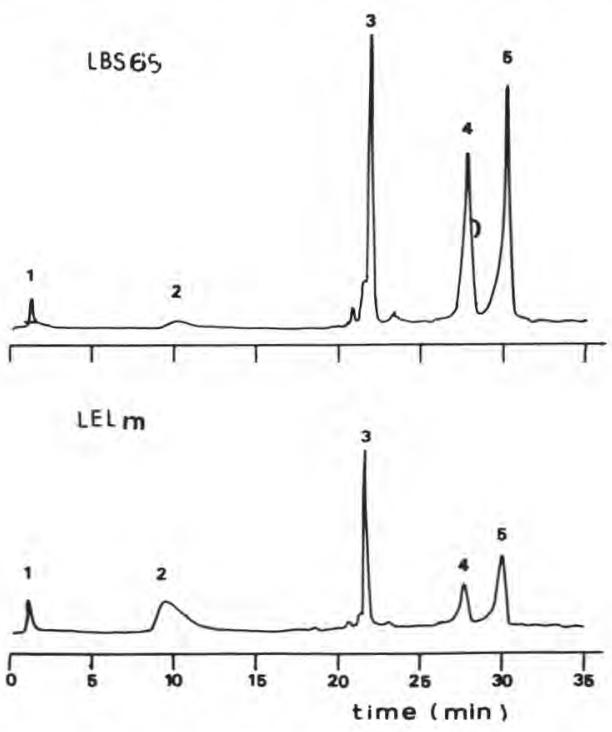

Fig 3. Chromatograms of LBS65 and LELm obtained with FPLC. Experimental conditions: Column Mono Q HP 5/5 (Pharmacia). Elution buffer: buffer A: Tris- $\mathrm{HCl} 20 \mathrm{mmol} / \mathrm{pH}$ 7, buffer B: Tris- $\mathrm{HCl} 20 \mathrm{mmol} / \mathrm{l} \mathrm{pH} 7+\mathrm{NaCl} 0.35 \mathrm{~mol} / \mathrm{l}$. Elution: buffer $A(3 \mathrm{~min})$ linear gradient from 0 to $100 \%$ of buffer B (20 min). Buffer B (12 min). Solution of peptides: $10 \mathrm{mg} / \mathrm{ml}$. Injection: $200 \mu \mathrm{l}$. 1: immunoglobulins, 2: lactoferrin, 3: $\alpha$ lactalbumin, 4: B lactoglobulin A, 5: B lactoglobulin B.

Analyse par FPLC des protéines contenues dans LBS65 et LELm. Conditions expérimentales: Colonne Mono Q HP 5/5 (Pharmacia). Tampon d'élution: A: Tris- $\mathrm{HCl} 20 \mathrm{mmol} / \mathrm{pH} 7$; B: Tris- $\mathrm{HCl} 20 \mathrm{mmol} / \mathrm{pH} 7+\mathrm{NaCl} 0.35 \mathrm{~mol} / \mathrm{l}$. Elution: tampon A ( $3 \mathrm{~min})$, gradient linéaire de 0 à 100\% de tampon B (20 min). Tampon B: 12 min. Injection: $200 \mu \mathrm{l}$ d'une solution à $10 \mathrm{mg} / \mathrm{ml}$ de peptides. 1: immunoglobulines, 2: lactoferrine, 3: $\alpha$ lactalbumine, 4: $\beta$ lactoglobuline $A, 5$ : $\beta$ lactoglobuline $B$. 
Table I. Antibody concentration measured in medium of $\mathrm{A}_{49}$ and $\mathrm{F}_{34}$ cultures. Medium was supplemented either with FCS (10\% and $1 \%)$, or with whey fractions ( $9 \%$ plus $1 \%$ FCS). Concentration en anticorps mesurée dans le milieu des cultures $A_{49}$ et $F_{34}$. Le milieu était supplémenté soit en FCS (10\% et 1\%), soit en fractions de lactosérum ( $9 \%+1 \%$ FCS).

\begin{tabular}{|c|c|c|}
\hline \multirow{2}{*}{$\begin{array}{c}\text { RPMI } 1640 \\
\text { supplemented with: }\end{array}$} & \multicolumn{2}{|c|}{$\begin{array}{c}\text { Antibody concentration } \\
(\mathrm{mg} / \mathrm{ml})\end{array}$} \\
\hline & $\begin{array}{r}A_{49} \\
\lg M\end{array}$ & $\begin{array}{l}F_{34} \\
\lg G 1\end{array}$ \\
\hline FCS $10 \%$ & 6.6 & 4.5 \\
\hline LBS65 $9 \%+$ FCS $1 \%$ & 8 & 6.2 \\
\hline LELm 9\% + FCS $1 \%$ & 6.8 & 4.7 \\
\hline FCS $1 \%$ & - & $<1$ \\
\hline
\end{tabular}

in lactoferrin (28.5\%) while LBS65 only contained it in a small quantity $(3.5 \%)$.

Table III comprises data on the mineral composition. The high concentrations of calcium in whey fractions is explained by the addition of calcium during their preparation, and a proportion of this calcium will remain bound to the proteins.

The lipid composition of whey fractions is shown in table IV. Although the milk has been skimmed, whey fractions still contain triglycerides. The ratio of unsaturated/ saturated fatty acids differs from 1 fraction to the other. The liposoluble vitamins present in milk have disappeared during whey fraction preparation except for vitamin $E$ which is found in small amounts.

The levels of energetic compound are summarized in table $\mathrm{V}$. Whey fractions were characterized by a very high content of lactose, which was not removed by ultrafiltration at cut-off 10000 .

Data on steroid and peptide hormones is given in table VI. Whey fractions also contain cAMP not found in FCS.

\section{DISCUSSION}

Like whole milk, whey fractions were able to promote cell growth. They are less effective than FCS at the same concentration and cell cultures at long-term require at least $0.5-1 \%$ of FCS. The hybridoma were stable in medium supplemented with whey fractions, they continued to secrete antibodies as in medium supplemented with $10 \%$ FCS.

The whey fractions used in these experiments have different protein contents. The optimal protein concentration to stimulate cell growth seems to be 15-20 g/l (data not shown). Milk fractions contain, as FCS, binding proteins: $\beta$ lactoglobulin which binds hydrophobic molecules such as free fatty acids, triglycerides, vitamin $A$ or metals $(\mathrm{Zn}, \mathrm{Fe}, \mathrm{Cu})$ (Spieker-Polet and Polet, 1981). Lactoferrin, which is present in the whey fraction LELm, accounts for a great part in the mitogenic activity of milk (Nichols et al, 1989). It is an essential growth factor for human lymphocytic cell lines and it is used to manufacture defined serum-free media which promote growth comparable to media containing serum for various cell lines (Hashizume et al, 1983). Lactoferrin is able to bind 2 iron atoms per protein molecule (Masson et al, 1966). It is noteworthy that the level of iron in LELm is higher than in LBS65.

LELm has an amino-acid content of 291 $\mu \mathrm{mol} / /$ while LBS65 contains $3828 \mu \mathrm{mol} / \mathrm{l}$ and FCS $4640 \mu \mathrm{mol} / \mathrm{l}$. Levels of aminoacids may not play a great role in the mitogenic activity of whey fractions because the basal medium RPMI 1640 already contains an excess of amino-acids. The $\mathrm{NH}_{3}$ content is smaller in whey fractions. This compound is toxic for cells in culture.

Whey fractions, like FCS, include carnitine. Carnitine is essential for the intramitochondrial translocation of fatty acids and branched chain keto-acids and for the 
Table II. Concentration of nitrogen compounds contained in whey fraction LBS65 and LELm compared to FCS. Detection threshold of each method is also given. Ind: not detectable; ND: not determined.

Concentration en composés azotés des fractions de lactosérum LBS65 et LELm comparée au FCS. Le seuil de détection de chaque méthode est également indiqué; Ind : non détectable; ND : non déterminé.

\begin{tabular}{|c|c|c|c|c|}
\hline Component & Detection threshold & FCS & LBS65 & LELm \\
\hline Total proteins ( $g / l)$ & 5 & 38 & 42 & 11 \\
\hline Free amino acids $(\mu \mathrm{mol} / \mathrm{l})$ : & 1 & & & \\
\hline Ala & - & 938 & 509 & 16 \\
\hline Amino-butyric acid & - & 73 & 75 & - \\
\hline Arg & - & 21 & 48 & 10 \\
\hline$A s n+A s p$ & - & 86 & 388 & 43 \\
\hline Citrulline & - & 81 & 116 & 5 \\
\hline Cys & - & - & - & - \\
\hline Gix & - & 662 & 445 & 64 \\
\hline Gly & - & 693 & 459 & 32 \\
\hline His & - & 10 & 80 & 10 \\
\hline Hydroxyproline & - & 133 & Ind & Ind \\
\hline lle & - & 110 & 61 & Ind \\
\hline Leu & - & 246 & 97 & 2 \\
\hline Lys & - & 215 & 114 & 14 \\
\hline Met & - & 33 & 28 & Ind \\
\hline Orn & - & 216 & 257 & 15 \\
\hline Phe & - & 121 & 45 & Ind \\
\hline Pro & - & 226 & 74 & Ind \\
\hline Ser & - & 168 & 564 & 28 \\
\hline Tau & - & 165 & 127 & 11 \\
\hline Thr & - & 118 & 151 & 9 \\
\hline Tyr & - & 59 & 133 & 11 \\
\hline Val & - & 266 & 107 & 20 \\
\hline Total A A $(\mu \mathrm{mol} / \mathrm{l})$ & - & 4640 & 3828 & 291 \\
\hline $\mathrm{NH}_{3}(\mathrm{mg} / \mathrm{l})$ & 0.100 & 38.1 & 24.4 & 9.2 \\
\hline Creatinine (mg/l) & 2 & 31 & 13 & 8 \\
\hline Uric acid (mg/l) & 10 & 26 & ND & 15 \\
\hline L Carnitine $(\mu \mathrm{mol} / \mathrm{l})$ & - & 61 & 180 & 30 \\
\hline Histamine (nmol/l) & 1 & Ind & 26 & ND \\
\hline
\end{tabular}

elimination of toxic metabolites of acyl CoA excess (Borum, 1988). Carnitine is normally derived from dietary intake or endogenous synthesis in vivo. Synthesis occurs to a significant extent, but only in the liver and kidney in the human being (Cederblard et al, 1979). Carnitine could be a limiting factor for energy supply from fatty acids in vitro.

The mineral content of whey fractions differs from one to the other and it is very different from the FCS mineral content. LELm and particularly LBS65 have a high calcium concentration. A major proportion 
Table III. Osmolarity, pH, and mineral levels in whey fractions LBS65 and LELm compared to FCS. Osmolarité, $\mathrm{pH}$ et concentration en minéraux des fractions de lactosérum LBS65 et LELm comparés au FCS.

\begin{tabular}{lcccc}
\hline \multicolumn{1}{c}{ Component } & Detection threshold & FCS & LBS65 & LELm \\
\hline & & & & \\
\hline Osmolarity (mOsm/l) & & 304 & 138 & 57 \\
$\mathrm{pH}$ & & 8.02 & 6.75 & 7.21 \\
$\mathrm{Na}(\mathrm{g} / \mathrm{l})$ & 0.230 & 3.22 & 0.437 & $<0.230$ \\
$\mathrm{~K}(\mathrm{~g} / \mathrm{l})$ & 0.39 & 0.39 & 0.39 \\
$\mathrm{Cl}(\mathrm{g} / \mathrm{l})$ & 0.011 & 3.51 & 0.96 & 0.39 \\
$\mathrm{Ca}(\mathrm{mg} / \mathrm{l})$ & 0.355 & 128 & 800 & 207 \\
$\mathrm{P}(\mathrm{mg} / \mathrm{l})$ & 5 & 81 & 205 & 71 \\
$\mathrm{Mg}(\mathrm{mg} / \mathrm{l})$ & 5 & $\mathrm{ND}$ & 82 & 73 \\
$\mathrm{Fe}(\mathrm{mg} / \mathrm{l})$ & 5 & 1.63 & 0.49 & 1.58 \\
$\mathrm{Cu}(\mathrm{mg} / \mathrm{l})$ & 0.2 & 0.104 & $<0.104$ & 0.100 \\
$\mathrm{Zn}(\mathrm{mg} / \mathrm{l})$ & 0.104 & $\mathrm{ND}$ & 0.5 & $<5$ \\
$\mathrm{Se}(\mu \mathrm{g} / \mathrm{l})$ & 0.130 & $<5$ & $<5$ & $<5$ \\
\hline
\end{tabular}

Table IV. Lipids, fatty acids, liposoluble vitamins contained in whey fractions LBS65 and LELm compared to FCS. Ind: not detectable.

Concentrations en lipides, acides gras, vitamines liposolubles des fractions de lactosérum LBS65 et LELm comparées à celles du FCS. Ind = non détectable.

\begin{tabular}{|c|c|c|c|c|c|c|c|}
\hline Component & Detection threshold & \multicolumn{2}{|c|}{ FCS } & \multicolumn{2}{|c|}{ LBS65 } & \multicolumn{2}{|c|}{ LELm } \\
\hline Cholesterol (mg/l) & 50 & \multicolumn{2}{|c|}{360} & \multicolumn{2}{|c|}{190} & \multicolumn{2}{|c|}{60} \\
\hline Triglycerides (mg/l) & 200 & \multicolumn{2}{|c|}{900} & \multicolumn{2}{|c|}{1740} & \multicolumn{2}{|c|}{1410} \\
\hline Fatty acids (mg/l) & 1 & Free & Total & Free & Total & Free & Total \\
\hline Myristic & - & Ind & - & 25 & - & 4 & - \\
\hline Palmitic & - & 34 & 84 & 46 & 263 & 12 & 224 \\
\hline Palmitoleic & - & Ind & 17 & 2 & 14 & 5 & 16 \\
\hline Phytanic & - & Ind & Ind & Ind & 4 & Ind & Ind \\
\hline Stearic & _ & 39 & 39 & 32 & 95 & 7 & 202 \\
\hline Oleic & - & 48 & 113 & 23 & 226 & 7 & 150 \\
\hline Linoleic & - & 16 & 16 & 1 & 42 & 15 & 23 \\
\hline Linolenic & - & Ind & - & Ind & - & - & - \\
\hline Eicosatrienoic & - & - & Ind & - & 7 & - & Ind \\
\hline Arachidonic & - & - & 22 & - & 7 & - & Ind \\
\hline Total & - & 137 & 291 & 129 & 658 & 50 & 615 \\
\hline Ratio unsat/sat & - & 0.87 & 1.20 & 0.25 & 0.81 & 1.17 & 0.44 \\
\hline Vitamin D $(\mu \mathrm{g} / \mathrm{l})$ & 4 & \multicolumn{2}{|c|}{$<4$} & \multicolumn{2}{|c|}{$<4$} & \multicolumn{2}{|c|}{$<4$} \\
\hline Vitamin $E(\mathrm{mg} / \mathrm{l})$ & 0.2 & \multicolumn{2}{|c|}{1.1} & \multicolumn{2}{|c|}{0.6} & \multicolumn{2}{|c|}{0.4} \\
\hline Vitamin A $(\mu \mathrm{g} / \mathrm{l})$ & 90 & \multicolumn{2}{|c|}{$<90$} & \multicolumn{2}{|c|}{$<90$} & \multicolumn{2}{|c|}{$<90$} \\
\hline
\end{tabular}


Table V. Energetic component concentration in whey fractions compared to FCS.

Concentration en composants énergétiques des fractions de lactosérum comparée à celle du FCS.

\begin{tabular}{|c|c|c|c|c|c|}
\hline Component & Reference kits & Detection threshold & FCS & LBS65 & LELm \\
\hline Glucose (mg/l) & $\begin{array}{l}\text { Biotrol } \\
\text { ref A02463 }\end{array}$ & 70 & 860 & 90 & 50 \\
\hline Galactose (mg/l) & $\begin{array}{l}\text { Boeringher } \\
\text { ref } 124273\end{array}$ & 50 & $<50$ & $<50$ & 56.5 \\
\hline Lactose $(g / l)$ & $\mathrm{CPG}$ & 0.100 & - & 120 & 16 \\
\hline Pyruvate (mg/l) & $\begin{array}{l}\text { Boeringher } \\
\text { ref } 124982\end{array}$ & 0.8 & 1.3 & $<0.8$ & $<0.8$ \\
\hline Lactate (mg/l) & $\begin{array}{l}\text { Boeringher } \\
\text { ref } 256773\end{array}$ & 13 & 190 & 1481 & 73 \\
\hline
\end{tabular}

of this calcium could be bound to proteins (Harzer et al, 1986), which may be the reason for the nontoxicity of calcium. Iron and zinc are found in whey fractions. The iron concentration is higher than that reported by Blanc (1981) in whole bovine milk. It is known to stimulate cell growth (PerezInfante and Mather, 1982).

Although the milk was skimmed before use, whey fractions still contain cholesterol and triglycerides. It is well established that cholesterol is essential for the growth of mammalian cells in culture (Chen, 1984). It plays a role in maintaining the integrity of the cells and regulating the fluidity of cellular membrane lipids. Most cultured cells are able to synthesize cholesterol, but they also efficiently utilize cholesterol from the medium. The cholesterol supplementation was variable with the cell lines: $7.5 \mu \mathrm{g} / \mathrm{ml}$ for human fibroblasts (Ostlund and Yang, 1985), $40 \mu \mathrm{g} / \mathrm{ml}$ for human renal cells (Gonzalez et al, 1974), $1.9 \mu \mathrm{g} / \mathrm{ml}$ for BSC1 and human heart cells. However, autooxidation of cholesterol occurs during handling of culture media and oxysterols formed inhibit sterol synthesis and cell growth (Kandutsch et al, 1978). The whey fractions added to medium provide 17.1 $\mu \mathrm{g} / \mathrm{ml}$ of cholesterol (LBS65) or $5.4 \mu \mathrm{g} / \mathrm{ml}$ (LELm) while FCS supplies $36 \mu \mathrm{g} / \mathrm{ml}$. However, cholesterol must be transported by specific proteins to be biologically active; perhaps $\beta$ lactoglobulin plays this role?

FFA are also present in milk fractions. FFA may be required for cell growth as nutriment precursors, structural elements of cell membranes and prostaglandin precursors. Fatty acids can be synthesized by cells, but the cells preferentially use performed FFA from the medium. The FA composition of culture medium greatly influence the FA composition of cells, particularly FA of membrane phospholipids (Delplanque and Jacotot, 1987), FFA of whey fractions may be carried by proteins such as serum albumin and $\beta$ lactoglobulin (Spieker-Polet and Polet, 1981) and transferred from these proteins to the cells. The percentage of unsaturated FFA is higher in LELm than in LBS65 or in FCS.

Liposoluble vitamins normally present in the whole milk (Blanc, 1981) are largely lost during milk treatment. 
Table VI. Steroid and peptidic hormone contents of whey fraction compared to FCS. ND : not determined.

Concentration en hormones stéroïdes et peptidiques des fractions de lactosérum comparée à celle du FCS; ND = non déterminé.

\begin{tabular}{|c|c|c|c|c|c|}
\hline Component & Reference of kits & Detection threshold & FCS & LBS65 & LELm \\
\hline \multicolumn{6}{|l|}{ Steroids } \\
\hline $\begin{array}{l}\text { Dihydrostestosterone } \\
\text { (ng/l) }\end{array}$ & $\begin{array}{c}\text { Biomérieux } \\
\text { 3H-DHT RIA Kit }\end{array}$ & 50 & $<50$ & 50 & $<50$ \\
\hline Testosterone (ng/l) & $\begin{array}{c}\text { CIS } \\
\text { SB-Testo }\end{array}$ & 80 & $<80$ & $<80$ & $<80$ \\
\hline Cortisol $(\mu \mathrm{g} / \mathrm{l})$ & $\begin{array}{c}\text { Immunotech } \\
1114\end{array}$ & 4.6 & $<4.6$ & $<4.6$ & $<4.6$ \\
\hline $\begin{array}{l}17 \mathrm{OH} \text {-progesterone } \\
\text { (ng/l) }\end{array}$ & $\mathrm{CIS} \mathrm{OHP-H}$ & 60 & $<60$ & 160 & 130 \\
\hline Progesterone (ng/l) & $\begin{array}{c}\text { CIS } \\
\text { SB-PROG }\end{array}$ & 50 & $<50$ & 100 & 53 \\
\hline \multicolumn{6}{|l|}{ Peptides hormones } \\
\hline ACTH (ng/l) & $\begin{array}{c}\text { CIS } \\
\text { ACTH-PR }\end{array}$ & 10 & 10 & 68 & $<10$ \\
\hline $\mathrm{LH}(\mu \mathrm{g} / \mathrm{l})$ & $\begin{array}{c}\text { CIS } \\
\text { LHK-PR }\end{array}$ & 0.2 & $<0.2$ & 0.55 & ND \\
\hline $\mathrm{FSH}(\mu \mathrm{g} / \mathrm{l})$ & $\begin{array}{c}\text { CIS } \\
\text { FSHKPR }\end{array}$ & 0.3 & $<0.3$ & $<0.3$ & ND \\
\hline Insulin (mUI/I) & $\begin{array}{c}\text { CIS } \\
\text { SB-INSI-S }\end{array}$ & 2.5 & 4 & 4 & $<2.5$ \\
\hline Peptide C (nmol/l) & $\begin{array}{c}\text { CIS } \\
\text { IA-C-PEP }\end{array}$ & $\begin{array}{c}100 \\
\text { (bovine peptide C) }\end{array}$ & $<100$ & $<100$ & $<100$ \\
\hline Prolactin $(\mu \mathrm{g} / \mathrm{l})$ & Immunotech 2121 & 0.5 & 20 & 6 & ND \\
\hline $\mathrm{HGH}(\mu \mathrm{g} / \mathrm{l})$ & $\begin{array}{c}\text { CIS } \\
\text { SB-HGH }\end{array}$ & 0.25 & $<0.25$ & $<0.25$ & $<0.25$ \\
\hline $\begin{array}{l}\text { Somatomedin C } \\
(\mathrm{nmol} / \mathrm{l})\end{array}$ & $\begin{array}{c}\text { CIS } \\
\text { IN-SOMC }\end{array}$ & 2 & 11 & 3 & $<2$ \\
\hline Gastrin (ng/l) & $\begin{array}{c}\text { CIS } \\
\text { GASK-PR }\end{array}$ & 10 & 56 & 33 & $<10$ \\
\hline $\begin{array}{l}\text { Second messenger } \\
\text { cAMP }(\mathrm{nmol} / /)\end{array}$ & $\begin{array}{c}\text { CIS } \\
\text { CAMP-K }\end{array}$ & 0.2 & 1 & 325 & 592 \\
\hline
\end{tabular}

The presence of steroid hormones such as glucocorticoids, estrogen and progesterone is demonstrated in whole bovine milk (Koldovsky and Thornburg, 1987).
Amongst steroid hormones, only progesterone and $17-\mathrm{OH}$-progesterone are present in a measurable quantity in whey fractions. Progesterone has sometimes been added 
to defined culture media for hybridoma proliferation (Cleveland et al, 1983).

The levels of peptide hormones were underestimated because they were determined by RIA using antibodies against human hormones. Only ACTH and gastrin are present in appreciable amounts in the whey fraction (LBS65). ACTH has been described to stimulate hybridoma proliferation (Murakami et al, 1982). Prolactin is at a level lower than that in whole milk (Blanc, 1982).

Various growth factors which contribute to the growth promoting properties of milk have been found in human and bovine milks (Shing and Klagsbrun, 1984). A small amount of Sm-C is left behind in milk fractions. Other growth factors were not measured.

It is noteworthy that whey fractions are rich in CAMP, which seems to be assimilable by cells in culture. Perhaps it is bound to other molecules. In fact, its level decreases during cell proliferation and we have established that it is not merely destroyed during culture time.

Although cleared of casein and ultrafiltered (cut-off 10000 ) whey fractions are a complex medium containing various components able to promote cell growth. However, some compounds present in FCS and absent in milk fractions are required in long-term cell culturing.

\section{ACKNOWLEDGMENTS}

This work was supported by grants from Nancy I University, district de Nancy, Mission de la Recherche de la Région, Région de Lorraine and CEE (contrat BAP O129 F).

\section{REFERENCES}

Alais C (1984) Science du lait. Principes des techniques laitières, 4 Ed, Sepaic Paris
Andrews AT, Taylor MD, Owen AJ (1985) Rapid analysis of bovine milk proteins by fast protein liquid chromatography. $J$ Chromatogr $348,177-185$

Arnaud J, Bellanger J, Bienvenu F, Chappuis P, Favier A (1984) Méthode recommandée de dosage du zinc sérique par absorption atomique en flamme. Inf Sci Biol 10, 79-88

Blanc B (1981) Biochemical aspects of human milk. Comparison with bovine milk. World Rev Nutr Diet 36, 1-89

Blanc B (1982) Les protéines du lait à activité enzymatique. Lait 62, 350-395

Borum PR (1988) Carnitine function. In: Clinical Aspects of Human Carnitine Deficiency (Borum PR, ed) Pergamon Press, New York, 16-27

Campbell PG, Baumrucker CR (1989) Insulinlike growth factor I and its association with binding proteins in bovine milk. J Endocrinol $120,21-29$

Cederblard G, Lindstedts G (1972) A method for the determination of carnitine in the picomole range. Clin Chim Acta 37, 235-243

Cederblard G, Holm J, Lindstedts G, Nordin I, Schersten T (1979) $\gamma$ butyrobetaine hydroxylase activity in human and ovine liver and skeletal muscle tissue. FEBS Lett 98, 57-60

Chen HW (1984) Role of cholesterol metabolism in cell growth. Fed Proc 43, 126-130

Cleveland WL, Wood I, Erlanger BF (1983) Routine large-scale production of monoclonal antib odies in a protein free culture medium. J Immunol Methods 56, 221-234

Damerdji O, Derouiche F, Legrand C, Capiaumont J, Bour JM, Maugras M, Belleville $F$, Nabet $P$, Paquet $D$, Linden $G$ (1988) Utilization of whey fractions as a substitute for fetal calf serum in culture media. Biotechnol Tech 2, 253-258

Delplanque B, Jacotot B (1987) Influence of environmental medium on fatty acid composition of human cells: leukocytes and fibroblasts. Lipids 22, 241-249

Derouiche F, Bour JM, Legrand C, Capiaumont J, Belleville F, Linden G, Nabet P (1989) Improved long-term storage of hybridoma at $-80{ }^{\circ} \mathrm{C}$ using a bovine milk derivative. $\mathrm{J} / \mathrm{m}$ munol Methods 125, 13-18 
Dubois F, Teby A, Belleville F, Nabet P, Paysant $P$ (1990) Valeurs usuelles du sélénium sérique dans une population de l'Est de la France. Ann Biol Clin 48, 28-32

Folch J, Lees M, Stanley GHS (1957) A simple method for the isolation and purification of total lipids from animal tissues. $J$ Biol Chem 226, 497-509

Garcia J, Ghisolfi J, Lapalu-Traun G, Periquet B, Olives JP, Boyer MJ, Thouvenot JP (1986) Dépistage d'une carence en acides gras essentiels chez l'enfant. Intérêt respectif du dosage des acides gras dans les lipides totaux et les fractions lipidiques du sérum. Ann Biol Clin 44, 380-383

Gelot MA, Jeandel C, Belleville F, Nabet P, Pénin F, Cuny $G(1990)$ Acides aminés du liquide céphalo-rachidien dans la maladie d'Alzheimer. Ann Biol Clin 48, 182-184

Gonzalez R, Dempsey ME, Elliot AY, Fraley EE (1974) Studies of sterol synthesis, synthesis regulation and transport in cultured human kidney. Exp Cell Res 87, 152-158

Hansen LG, Warnick WS (1969) Fluorimetric micromethod for vitamin A and E. Am J Clin Pathol 51, 538-541

Hansen LG, Warnick WJ (1968) A fluorimetric micromethod for serum vitamin A. Tech Bull Regist Med Technol 9, 239-243

Harzer G, Hang M, Bindels JG (1986) Biochemistry of human milk in early lactation. $Z \mathrm{Er}$ naehrungswiss 25, 77-90

Hashizume S, Kuroda K, Murakami H (1983) Identification of lactoferrin as an essential growth factor for human lymphocytic cell lines in serum-free medium. Biochim Biophys Acta 763, 377-382

Ichida I (1968) A simple method for the determination of serum iron. Clin Chim Acta 22, 271275

Kandutsch AA, Chen HW, Heiniger HJ (1978) Biological activity of some oxygenated sterols. Science 202, 498-501

Koldovsky O, Thornburg W (1987) Hormones in milk. J Pediatr Gastroenterol Nutr 6, 172-196
Masson PL, Heremans JF, Prignot JJ, Wauters G (1966) Immunohistochemical localization and bacteriostatic properties of an iron binding protein from bronchial mucus. Thorax 21, 538-544

Maubois JL, Léonil J (1989) Peptides du lait à activité biologique. Lait 69, 245-265

Murakami $H$, Masui $H$, Sato $G H$, Sueoka N, Chow TP, Kano-Sueoka T (1982) Growth of hybridoma cells in serum-free medium: ethanolamine is an essential component. Proc Natl Acad Sci USA 79, 1158-1162

Nano JL, Vermeulen L, Rampal P (1982) Utilisation des protéines du lait comme milieu nutritif dans les cultures cellulaires. Lait 62, 600606

Nichols BL, Mc Kee K, Putman M, Henry JF, Nichols VN (1989) Human lactoferrin supplementation of infant formulas increases thymidine incorporation into the DNA of rat crypt cells. J Pediatr Gastroenterol Nutr 8, 102-109

Ostlund RE, Yang JW (1985) Effect of cholesterol and growth factors on the proliferation of cultured human skin fibroblasts. Exp Cell Res 161, 509-516

Perez-Infante V, Mather JP (1982) The role of transferrin in the growth of testicular cell lines in serum-free medium. Exp Cell Res 142, 325-332

Sarkar BC, Chauhan UP (1967) A new method for determining micro quantities of calcium in biological materials. Anal Biochem 20, 155166

Serini A, Baserga $R$ (1981) Routine growth of cell lines in medium supplemented with milk instead of serum. Cell Biol Int Rep 5, 339345

Shing YW, Klagsbrun M (1984) Human and bovine milk contain different sets of growth factors. Endocrinology 115, 273-282

Spieker-Polet E, Polet H (1981) Requirement of a combination of a saturated and an unsaturated free fatty acid and a fatty acid carrier protein for in vitro growth of lymphocytes. $J$ Immunol 126, 949-954 